\title{
An Evaluation on Bridge Bearing Capacity under Scour and Re-occurrence of Strong Earthquake
}

\author{
Huang XIANBIN, Liu CHENYANG, Hou SONG, Chen CHUNYANG, Mei YUJIAO, Lei BO, Huang YONG
}

\begin{abstract}
Plagued by frequent calamities, Bridge No.3 encountered magnitude-8 earthquake on May 12, 2008 and several years later its pile foundation was intensively scoured. The smallest scour depth was 4.5 meters and the largest scour depth was 9.2 meters. Considering intense scour and re-occurrence of strong earthquake, the Chinese existing standard and seismic response analysis are used to study bearing capacity and seismic performance of pier and pile foundation of Bridge No.3 before and after scour. It is proved by calculation that the bridge is stable before scour and can hardly bear strong earthquake and intense scour after scour, therefore consolidation is required. The study result may serve as an important reference for the bridge affected by serious scour and strong earthquake.
\end{abstract}

Keywords: axial force; bending moment; pile; reoccurrence of strong earthquake; scour

\section{INTRODUCTION}

China is an earthquake-prone country where major earthquakes have frequently occurred in recent years, including the earthquake that happened in Dongguan, Haicheng, Tangshan, Songpan, Wenchuan, Yushu and Lushan in 1974, 1975, 1976, 2008, 2010 and 2013 respectively [1]. Numerous bridges were seriously damaged during earthquake, among which Beam-shape bridge was the bridge mostly affected. As load-carrying members, the bridge pier and pile foundation would lead to traffic interruption if damaged, causing great economic loss. See Deng J. [2], Study on Repaired EarthquakeDamaged Bridge Piers under Seismic Load; Chung Y. S. [3], Residual earthquake resistance performance of reinforced concrete bridge piers after moderate earthquakes; Wu Z. J. [4], Hsu [5]. Du Xiuli [6] conducts in-depth research on seismic performance of bridge pier and analysis model Zhang L [7], a series of seismic centrifuge model tests were performed to study the behavior of pile groups in soft kaolin clay. Ma K. [8], a range of centrifuge shaking table tests were carried out at the National University of Singapore to examine the seismic softening behavior of pile-raft foundation constructed in clayey soil site which is subjected to far field earthquake. Kumar A. [9], Luo C. [10] and Al-Defae A. H. [11] perform a study on seismic performance of pile foundation, finding that the bridge seismic performance not only touches upon bridge structure but it relates to boundary condition. Since dynamic is a key matter for bridge seismic research, the river bed scour weakens seismic capacity of pile foundation and changes structural dynamic performance as well, consequently further swaying seismic response. Therefore, the effect exerted by river bed scour on seismic performance of pile foundation is complex. Currently, there are few examples in literature that study the effect on bridge seismic performance caused by pile foundation scour [12]. The bridge is damaged during earthquake, leading to seismic capacity deterioration. This is often accompanied by heavy rainfall which inflicts flood scour. The problem--the change of river bed further weakens bridge seismic capacity--must be considered in the bridge seismic analysis and consolidation plan after earthquake. As China road construction will soon come to an end, the majority of bridges will embrace maintenance period. It can be foreseen that the maintenance and consolidation will become a mainstream orientation for bridge construction. In this paper, the seismic response analysis is performed based on actual scour situation of pile foundation of Bridge No.3, and bearing capacity of stud pier and pile foundation is evaluated per formula calculation. The seismic wave derives from the earthquake data collected from the Wenchuan earthquake epicenter network. The wave is input into bridge model as earthquake wave to conduct seismic response analysis, so as to assume that bridge structure re-suffers from the Wenchuan magnitude- 8 earthquake and to see its seismic response.

\section{PROJECT PROFILE 2.1 Bridge Profile}

Situated in Jinma river reach, Minjiang river, Dujiangyan city, Bridge No. 3 is adjacent to Wenjiang district of Chengdu, which is an important road between Jiahong and Mount Qingcheng and is 30 kilometers away from the epicenter of magnitude- 8 Wenchuan earthquake. The top part of bridge adopts $27 \times 20 \mathrm{~m}$ simply supported hollow rectangular plate made up of pre-stressed concrete, with concrete used for main girder being $\mathrm{C} 40$. The bottom part is designed in the form of three-column circularsection piers featuring single-row reinforced concrete. The bridge pier has a diameter of 1.3 meters. The frictional pile foundations all employ $\mathrm{C} 30$ reinforced concrete, with pile diameter of 1.5 meters. The general pile is originally designed as 24 meters, with the shortest pile being 18 meters and the longest pile 29 meters. The No. 1, No. 2, No. 25 and No. 26 bridge piers and expansion joints should be equipped with GJZF4 slide-plate rectangle rubber support. The bridge floor succession area should be fitted with GJZ slide-plate rectangle rubber support. The laminated rubber support shows poor stability during earthquake, and at the area where main girder is connected to pier easily causes horizontal and longitudinal displacement [13]. The bridge is exposed to basin subtropical climate that is warm and rainy. the average rainfall is $964.2 \mathrm{~mm}$, the maximum rainfall is $1820.7 \mathrm{~mm}$ and the maximum rainfall is $273.7 \mathrm{~mm}$ for the past 24 
hours. The average gradient of river bed is 0.47 percent. The geological condition of pile foundation for No.5 pier is similar to that of No. 16 pier, where below river bed is $4.5 \mathrm{~m}$-deep gravel sand and down to the bottom of pile foundation is land pebble. There is $9 \mathrm{~m}$-deep land pebble containing silt below No. 9 pile foundation whose geology is soft comparing with other pile foundations. When the bridge was designed and constructed, the seismic intensity in Dujiangyan was 7 magnitude [14], peak acceleration
$0.10 \mathrm{~g}$ and seismic response spectrum $0.40 \mathrm{~s}$. On May 12 2018, a strong magnitude-8 earthquake occurred in Wenchuan. And China has changed seismic intensity of Dujiangyan to magnitude 8 and peak acceleration value $0.20 \mathrm{~g}[15]$. The seismic grouping falls under group II and seismic response spectrum is $0.40 \mathrm{~s}$. See Fig. 1 for the relative position of bridge and surrounding strong earthquake stations.

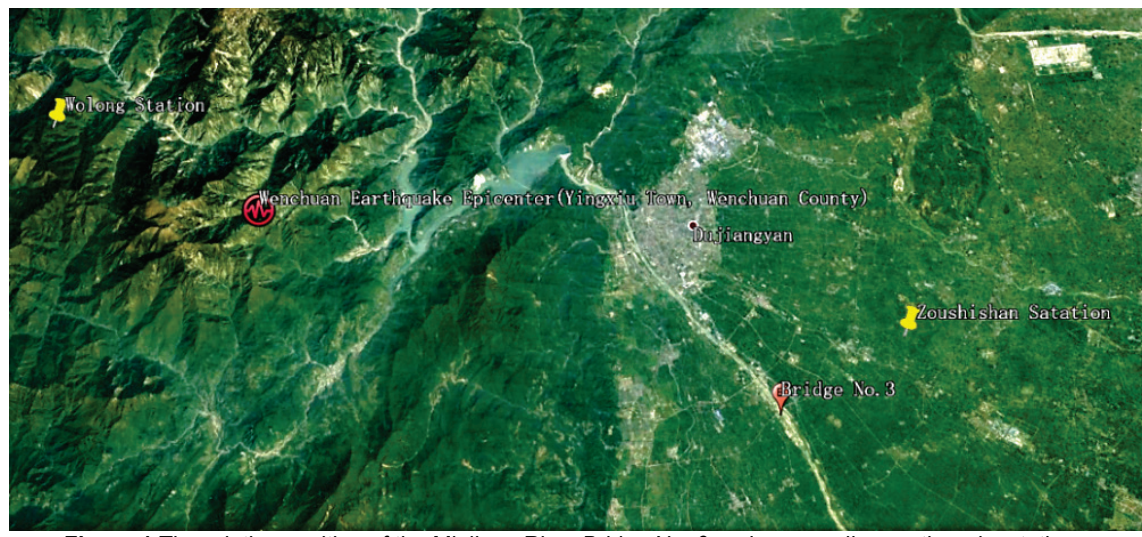

Figure 1 The relative position of the Minjiang River Bridge No. 3 and surrounding earthquake stations

Table 1 The scour depth of pile foundation in main river

\begin{tabular}{|c|c|c|c|c|c|c|c|c|c|c|c|c|c|}
\hline Tier number & 10 & 11 & 12 & 13 & 14 & 15 & 16 & 17 & 18 & 19 & 20 & 21 & 22 \\
\hline Scour height $/ \mathrm{m}$ & 7.0 & 6.3 & 6.3 & 6.5 & 6.5 & 7.0 & 9.0 & 9.0 & 6.3 & 9.2 & 4.5 & 4.5 & 4.5 \\
\hline Pile length / $\mathrm{m}$ & 24 & 24 & 24 & 24 & 24 & 24 & 24 & 24 & 24 & 24 & 24 & 24 & 24 \\
\hline
\end{tabular}

\subsection{Bridge Damage Status}

The bridge test report shows [16] that due to the Wenchuan earthquake in the partial expansion joint of Bridge No.3 is observed deformation and displacement and that in partial support is seen deflection and twist and in some pile foundations appear cracks. The bridge has experienced intense scour in recent years, and the scour severity is shocking.

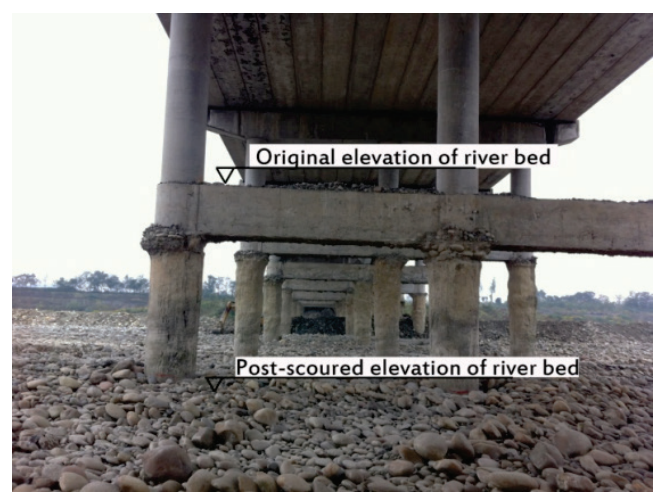

Figure 2 The vertical and horizontal pile foundation scour photo of Minjiang River Bridge No. 3

See Fig. 2 for whole and local scour situation of pile foundation. Being 25 kilometers away from Zipingpu reservoir, Bridge No. 3, Zipingpu reservoir was put into use in 2010. The reservoir significantly reduces sand content in the Jinma river by blocking bed load sediment and precipitation suspended load sediment. The flood may intensify the river bed scour of the Jinma river. And illegal gravel collection aggravates pile foundation exposure. The scour depth of pile foundation at main river ranges from
4.5 meters to 9.2 meters, of which average scour depth is 6.9 meters. The smallest scour depth is 4.5 meters and the largest scour depth is 9.2 meters, see Tab. 1. Comparing with embedded depth of pile foundation, the scour causes pile foundation to be embedded far less deep than expected in river, which seriously affects vertical bearing capacity of pile foundation and dramatically reduces horizontal earth resistance surrounding pile foundation [17].

\section{ANALYSIS OF BRIDGE BEARING CAPACITY BEFORE SCOUR}

\subsection{Bridge Finite Element Model}

Establish non-linear finite element model of Bridge No. 3 with Midas/Civil software. The bridge uses space beam column unit, and simulates support using elastic connection. The steel adopts two-broken line model. The concrete uses Mander model and pile foundation considers the interaction of soil structure [18-20]. The soil spring stiffness is established as per actual soil layer information, see Fig. 3. Set up four models including the fixed connection of pier bottom (without considering soil elasticity) and soil-structure (considering soil elasticity) before scour, and the fixed connection of pier bottom and soil structure after scour.

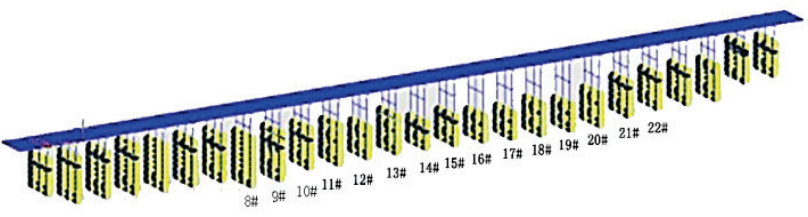

Figure 3 The finite element model of Minjiang River Bridge No. 3 


\subsection{Bridge Vibration Performance}

By means of modal analysis of soil stracture model, the natural period of vibration and vibration mode before and after is obtained for Bridge No. 3, see Tab. 2.

Table 2 Natural vibration period and vibration mode before and after scour

\begin{tabular}{|c|c|c|c|c|c|c|c|}
\hline \multirow[b]{2}{*}{$\begin{array}{c}\text { Modal } \\
\text { No. }\end{array}$} & \multicolumn{3}{|c|}{ Before scour } & \multicolumn{3}{|c|}{ After scour } & \multirow[b]{2}{*}{$\mathrm{T} 1 / \mathrm{T} 2$} \\
\hline & $\begin{array}{l}\text { Natural vibration } \\
\text { period } \mathrm{T} 1 \mathrm{(s)}\end{array}$ & $\begin{array}{l}\text { Natural vibration } \\
\text { frequency }(\mathrm{Hz})\end{array}$ & Description & $\begin{array}{c}\text { Natural vibration } \\
\text { period T2 (s) }\end{array}$ & $\begin{array}{l}\text { Natural vibration } \\
\text { frequency }(\mathrm{Hz})\end{array}$ & Description & \\
\hline 1 & 1.701 & 0.588 & along-bridge & 2.625 & 0.381 & along-bridge & 0.648 \\
\hline 2 & 1.499 & 0.667 & along-bridge & 2.046 & 0.489 & along-bridge & 0.733 \\
\hline 3 & 1.399 & 0.715 & along-bridge & 1.771 & 0.565 & along-bridge & 0.790 \\
\hline 4 & 1.298 & 0.77 & along-bridge & 1.561 & 0.641 & along-bridge & 0.832 \\
\hline 5 & 1.211 & 0.826 & along-bridge & 1.414 & 0.707 & along-bridge & 0.856 \\
\hline 6 & 1.127 & 0.887 & along-bridge & 1.279 & 0.782 & along-bridge & 0.881 \\
\hline 7 & 1.051 & 0.951 & along-bridge & 1.166 & 0.858 & along-bridge & 0.901 \\
\hline 8 & 0.987 & 1.013 & along-bridge & 1.094 & 0.914 & across-bridge & 0.902 \\
\hline 9 & 0.935 & 1.069 & along-bridge & 1.075 & 0.93 & Horizontal torsion & 0.870 \\
\hline 10 & 0.89 & 1.124 & along-bridge & 1.039 & 0.963 & Vertical torsion & 0.857 \\
\hline 11 & 0.849 & 1.177 & along-bridge & 1.007 & 0.993 & along-bridge 19\# Pier & 0.843 \\
\hline 12 & 0.828 & 1.208 & across-bridge & 0.957 & 1.044 & across-bridge 19\# Pier & 0.865 \\
\hline 13 & 0.813 & 1.229 & along-bridge 19\# Pier & 0.951 & 1.051 & along-bridge & 0.855 \\
\hline 14 & 0.787 & 1.271 & across-bridge 19\# Pier & 0.904 & 1.106 & along-bridge & 0.871 \\
\hline
\end{tabular}

\subsection{An Analysis of Bearing Capacity before Scour}

Built in 2005, Bridge No. 3 features original design condition that satisfies bridge design loading class-II and the seismic intensity-magnitude 7 . It is shown that the general pile is stable through calculation, preliminary bridge test result and long-term use. By inputting Wolong seismic wave, the analysis is carried out to seismic response of bridge via three earthquake motions from Zoushishan earthquake wave, see Fig. 4.

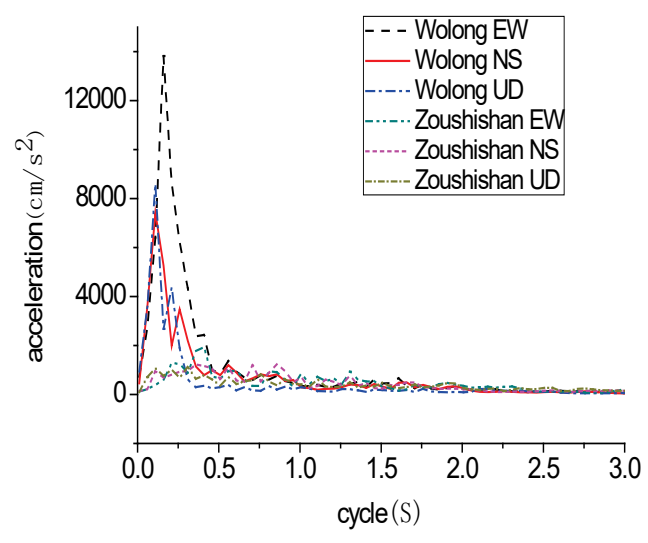

Figure 4 The ground motion response spectrum

The maximum bending moment of bridge pier is 3688 $\mathrm{kN} \cdot \mathrm{m}$ which is less than yielding moment that is 4045.8 $\mathrm{kN} \cdot \mathrm{m}$ (the maximum bending moments indicated in this paper are all along-bridge, for that along-bridge bending moment is greater than across-bridge bending moment). The bending moment satisfies requirement. The maximum axial force of bridge pier is $3888.3 \mathrm{kN}$ (compressed) which is less than compression bearing capacity of pier that is $6084.3 \mathrm{kN}$. For pile foundation, the maximum axial force of pile foundation is $4951.5 \mathrm{kN}$ (compressed) which is less than compression bearing capacity that is $8132.5 \mathrm{kN}$. Exposed to Wolong seismic wave, the maximum value of bending moment of No. 9 pile foundation is -5079.8 $\mathrm{kN} \cdot \mathrm{m}$, which is slightly greater than yielding moment that is $4787 \mathrm{kN} \cdot \mathrm{m}$ obtained through M- $\phi$ curve. The No. 9 pile foundation will be impaired (the geology of No. 9 pile foundation is soft), which is virtually consistent with actual seismic damage, see Fig. 5. The analysis implies that the Bridge No. 3 pile is generally stable under normal use before scour, however No. 9 pile can hardly bear strong earthquake.

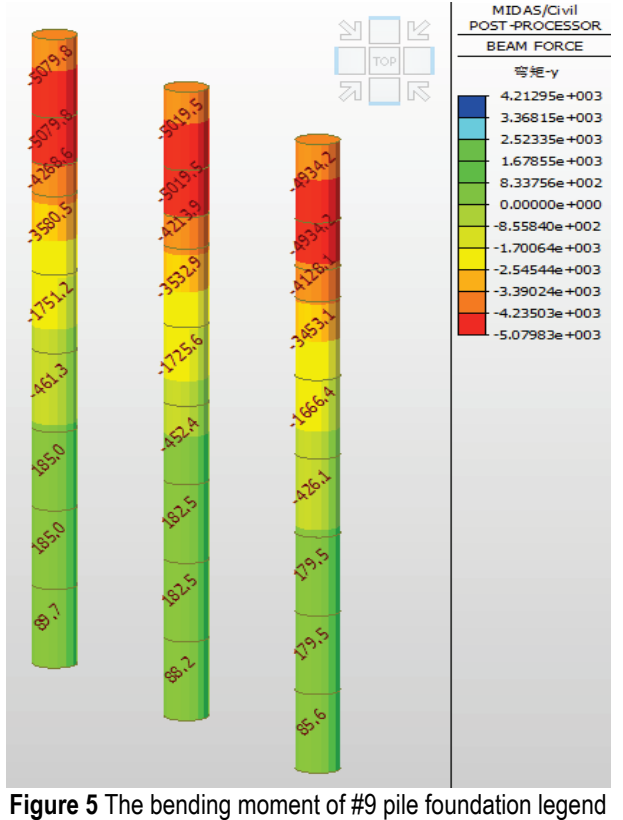

4 AN ANALYSIS OF BRIDGE BEARING CAPACITY IRRESPECTIVE OF STRONG EARTHQUAKE AND EXISTING SCOUR CONDITION

4.1 Checking Calculation for Bearing Capacity of Pier and Pile

The bearing capacity of circular pier stud can refer to Standard [21], see Eq. (1) and Eq. (2).

$r_{0} N_{d} \leq A r^{2} f_{c d}+C \rho r^{2} f_{s d}^{\prime}$ 


$$
r_{0} N_{d} e_{0} \leq B r^{3} f_{c d}+D \rho g r^{3} f_{s d}^{\prime}
$$

The $A$ and $B$ covered in the formula refer to calculation coefficient of concrete bearing capacity, $C$ and $D$ refer to calculation coefficient for bearing capacity of longitudinal bar, $r$ is the radius of the circular section, $g$ refers to the ratio of radius of longitudinal bar and peripheral radius, $\gamma_{0}$ is an important coefficient of bridge structure, $N_{d}$ refers to combined design value of axial force, $N_{d}$ equals $1.2 \times$ dead load plus $1.4 \times$ live load, of which the axial force of dead load generated is $3471.5 \mathrm{kN}$ and live load generated is $791.1 \mathrm{kN}$.

According to calculation, the compression axial force value of pier and pile is $6084.3 \mathrm{kN}$, which is $4262.6 \mathrm{kN}$ greater than actual axial force. The flexural force value is $4045.8 \mathrm{kN} \cdot \mathrm{m}$ which is greater than actual bending moment. The $4262.6 \mathrm{kN}$ and $648.2 \mathrm{kN} \cdot \mathrm{m}$ are the actual bearing capacity and bending moment of bridge provided in bridge test report [18].

The calculation shows that the bearing capacity of pier and pile under scour and normal use satisfies requirement (without considering strong earthquake).

\subsection{Checking Calculation for Bearing Capacity of Pile Foundation}

According to site inspection of actual bridge, No. 19 pier and pile suffering the largest scour in the main river is selected for checking calculation. See Tab. 3 for the soil parameter of bridge foundation [22]. The bearing capacity of pile foundation should be calculated per Eq. (3) and (4) based on standard [23].

$$
\begin{aligned}
& {\left[R_{a}\right]=\frac{1}{2} u \sum_{i=1}^{n} q_{i k} l_{i}+A_{p} q_{r}} \\
& q_{r}=m_{0} \lambda\left[\left[f_{a 0}\right]+k_{2} \gamma_{2}(h-3)\right]
\end{aligned}
$$

where $\left[R_{a}\right]$ is the permissible value for load-carrying capacity of single pile, $u$ stands for perimeter of pile body, $A_{p}$ stands for sectional area of pile tip, $n$ stands for soil layers, $l_{i}$ stands for the thickness of each soil layer at bottom of pile cap or local scour line, $q_{i k}$ stands for the $l_{i}$ each soil layer and standard value of pile side friction, $q_{r}$ stands for permissible value for bearing capacity of pile tip soil, $\left[f_{a 0}\right]$ stands for permissible value of soil at pile top, $h$ stands for embedded depth of pile tip, $k_{2}$ stands for correction coefficient for depth of permissible bearing capacity, $\gamma_{2}$ stands for weighted average unit weight of soil above pile tip, if bearing stratum is below water level or is impermeable, obtain saturated unit weight regardless of water permeability of soil above pile tip. When water permeates into bearing stratum, the soil in water should obtain floating unit weight, $\lambda$ refers to correction factor, obtaining $0.7, m_{0}$ stands for the coefficient for slurry cleaning at bottom of pile hole, obtaining 1.0.

Calculated per Eq. (3) $\left[R_{a}\right]=7731.04 \mathrm{kN}$, which is greater than actual load of pile foundation calculated by Civil that is $5775.8 \mathrm{kN}$.

The calculation demonstrates that bearing capacity of pile foundation under scour and normal use meets requirement (without considering strong earthquake).

Table 3 Soil parameter value of Bridge No. 3

\begin{tabular}{|c|c|c|c|c|c|c|c|}
\hline Ground name & Unit weight & $\begin{array}{c}\text { Compression } \\
\text { modulus }\end{array}$ & $\begin{array}{c}\text { Deformation } \\
\text { modulus }\end{array}$ & $\begin{array}{c}\text { Permeability } \\
\text { coefficient }\end{array}$ & $\begin{array}{c}\text { Friction } \\
\text { coefficient } \mu\end{array}$ & $\begin{array}{c}\text { Allowable } \\
\text { bearing capacity }\end{array}$ & $\begin{array}{c}\text { Ultimate frictional } \\
\text { resistance }\end{array}$ \\
\hline Unit & $\mathrm{kN} / \mathrm{m}^{3}$ & $\mathrm{MPa}$ & $\mathrm{MPa}$ & $\mathrm{m} / \mathrm{d}$ & - & $\mathrm{kPa}$ & \\
\hline Gravel & 19 & 7.2 & 10 & 70 & 0.38 & 160 \\
\hline Disturbed pebble & 20 & $/$ & $/$ & 130 & 0.48 & & $/$ \\
\hline $\begin{array}{c}\text { Gravel containing } \\
\text { soil }\end{array}$ & 20.5 & 15 & 23 & 60 & 0.43 & 60 \\
\hline Land pebble & 21.5 & 18 & 35 & 90 & 0.5 & 400 \\
\hline
\end{tabular}

\subsection{Checking Calculation for Flexural Bearing Capacity of Pile Foundation under Flood}

As per standard [24], the flowing water acted upon pile cap and foundation is calculated based on Eq. (5).

$F_{w}=K A \frac{\gamma V^{2}}{2 g}$

where $K$ refers to shape factor, the pile cap is calculated as 1.2 and pile foundation is obtained as $0.8, g$ refers to acceleration of gravity, $A$ refers to water-blocking area which calculates till general scour, $V$ refers to design discharge velocity and is considered as $5 \mathrm{~m} / \mathrm{s}$ according to flood period, $\gamma$ acts as gravity density of water.

See Tab. 4 for flexural capacity of pile foundation under floor.

The calculation shows that pile foundation fails to satisfy requirement under scour and normal use.

\section{AN ANALYSIS OF BRIDGE BEARING CAPACITY CONSIDERING STRONG EARTHQUAKE AND EXISTING SCOUR}

\subsection{An Analysis on the Seismic Performance of Bridge Column and Pile under Existing Scour}

Bridge No. 3 is about 51 kilometers away from Wolong station and 7 kilometers away from Zoushishan station. The earthquake record is used as an inputting earthquake wave to perform analysis of non-linear seismic response. The whole bridge is equipped with 26 piers (each pier is fitted with three pier studs), in which a study is conducted to all piers and pier studs. It is tricky to consider the scour effect in analyzing bridge seismic response [12]. The paper studies the bearing capacity of bridge under strong earthquake and existing scour.

Affected by Wolong and Zoushishan earthquake wave, the bridge pier and pier stud demonstrate its maximum axial force as $2878.7 \mathrm{kN}$ (compressed) obtained through Civil software after soil consolidation scour, which is less than compression bearing capacity $6084.3 \mathrm{kN}$ calculated 
per Eq. (1). This indicates that all bridge piers and pier studs satisfy bearing capacity requirement. The maximum bending moment of bridge pier calculated through Civil is $2469.5 \mathrm{kN} \cdot \mathrm{m}$ obtained through Civil software, which is less than yielding bending moment $4045.8 \mathrm{kN} \cdot \mathrm{m}$. The analysis shows bearing capacity of bridge pier meets requirement under earthquake.

Influenced by Wolong and Zoushishan earthquake wave, the pile foundation demonstrates its maximum axial force as $5875.9 \mathrm{kN}$ (compressed), which is less than allowable compression bearing capacity that is $6132.5 \mathrm{kN}$ calculated per Eq. (3) and (4). The compression axial force gratifies requirement. Nevertheless, the maximum bending moment of pile foundation $15-1,15-3$ and $16-3$ is 4824.5 , 5206.9 and 5229.9 respectively, which is greater than yielding bending moment $4787.7 \mathrm{kN} \cdot \mathrm{m}$ obtained through M- $\phi$ curve.

Table 4 The calculation result of pile foundation strength under flood

\begin{tabular}{|c|c|c|c|c|c|}
\hline Force & Stress property & $\begin{array}{l}\text { Axial force combination } \\
(\mathrm{kN})\end{array}$ & $\begin{array}{l}\text { Section resistance } \\
(\mathrm{kN})\end{array}$ & Degree of safety & If meet requirement \\
\hline Maximum bending moment & Drop down bias pressure & 3799.8 & 2283.8 & 0.6 & no \\
\hline Minimum bending moment & Drop down bias pressure & 3166.5 & 2284.8 & 0.72 & no \\
\hline Maximum axial force & Drop down bias pressure & 3799.8 & 2285.8 & 0.60 & no \\
\hline Minimum axial force & Drop down bias pressure & 3166.5 & 2286.8 & 0.72 & no \\
\hline
\end{tabular}

This would cause pile foundation No. 15-1, 15-3, 16-3 to be bent, see Fig. 6. The No. 16 - No. 17 pier girder shows a displacement of $17.9 \mathrm{~cm}$, which may drop apart, see Fig. 7.

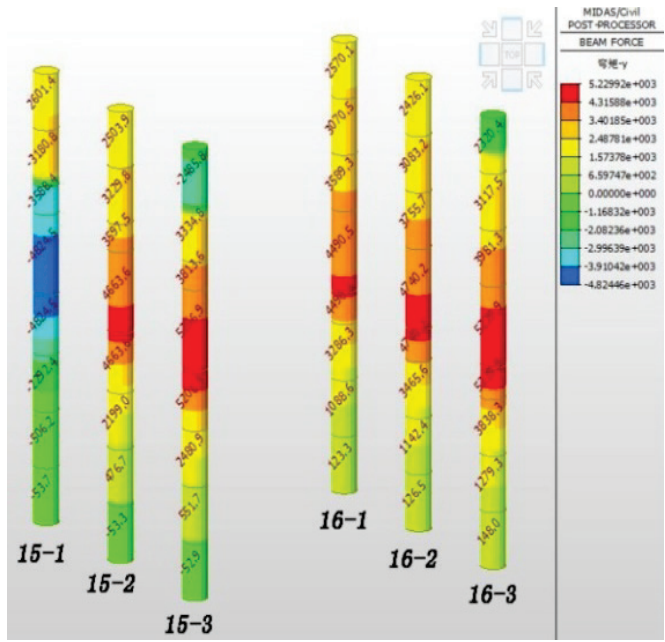

Figure 6 The maximum bending moment of \#15 and \#16 pile foundation legend

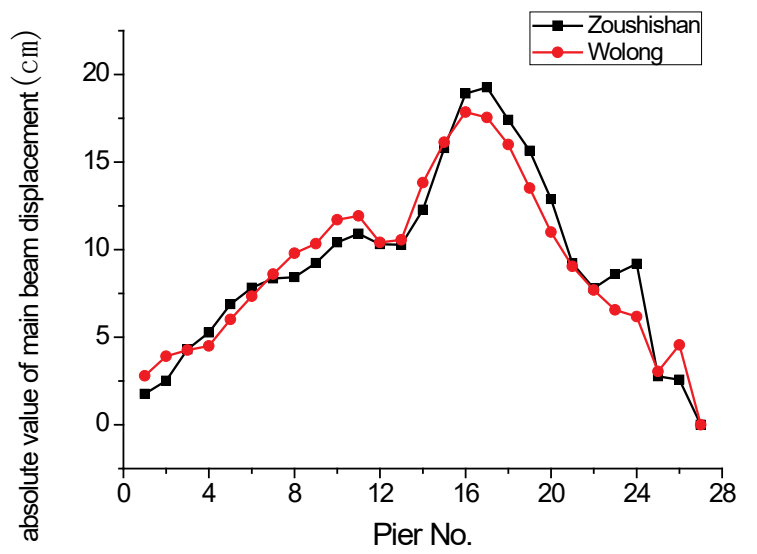

Figure 7 The absolute value of the maximum displacement of the main beam along bridge

The analysis indicates that bridge pier itself is safe under existing scouring depth and reoccurrence of intense earthquake. However part of pile foundation will be damaged due to great bending moment. Bridge No. 3 can no longer bear intense earthquake and consolidation is urgently needed.

\subsection{An Analysis on Seismic Performance of Four Models}

The excessive structure inertia force and vibration displacement generated by strong earthquake motion are major reasons causing bridge seismic damage [25]. The analysis conducted to four models shows that the axial force and bending moment after scour is generally less than before no matter bridge pier endures axial force or bending moment, see Fig. 8 and Fig. 9. Wolong seismic wave impacts bridge greater than Zoushishan seismic wave does, causing bridge to be easily damaged.

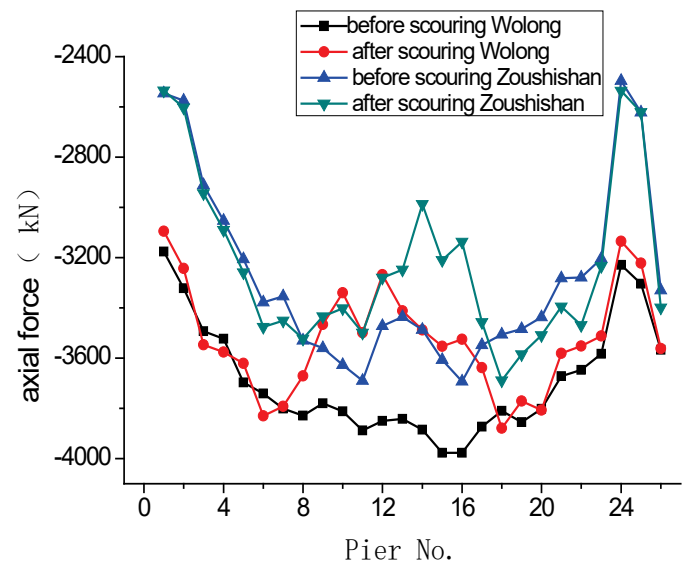

Figure 8 The maximum axial force $(\mathrm{kN})$ of the bridge pier under the SoilStructure Interaction

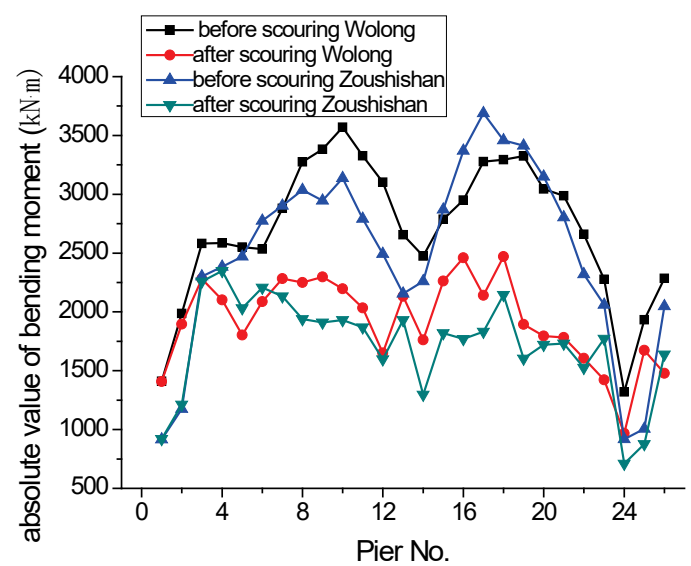

Figure 9 The maximum bending moment along bridge under the Soil-Structure Interaction 
The bending moment of pier stud under consolidation is less than fixed connection of pier bottom, see Fig. 10. The bridge girder shows greater displacement before scour than after. The girder displacement is greater than fixed connection of pier bottom. In the area subject to serious scour is observed great girder displacement, see Fig. 7 and Fig. 11. By conducting seismic response analysis to pile foundation, it is found that the maximum axial force and bending moment of pile after scour is greater than before, and the area where scour is serious will lead to great bending moment of pile foundation, see Fig. 12 and Fig. 13 .

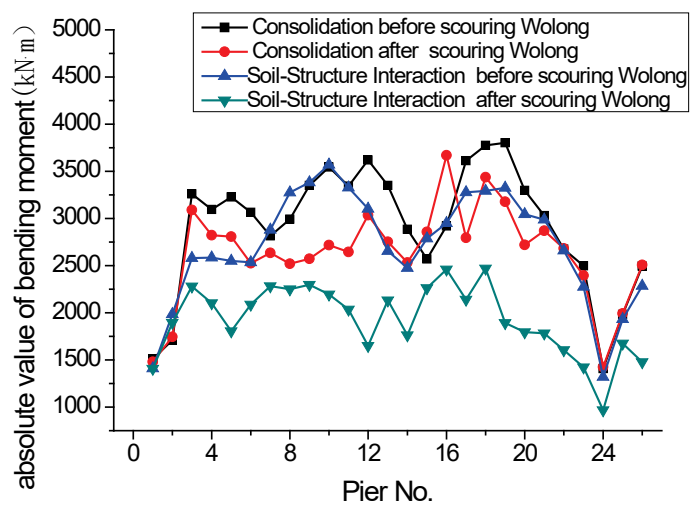

Figure 10 The maximum bending moment of pier bottom along bridge

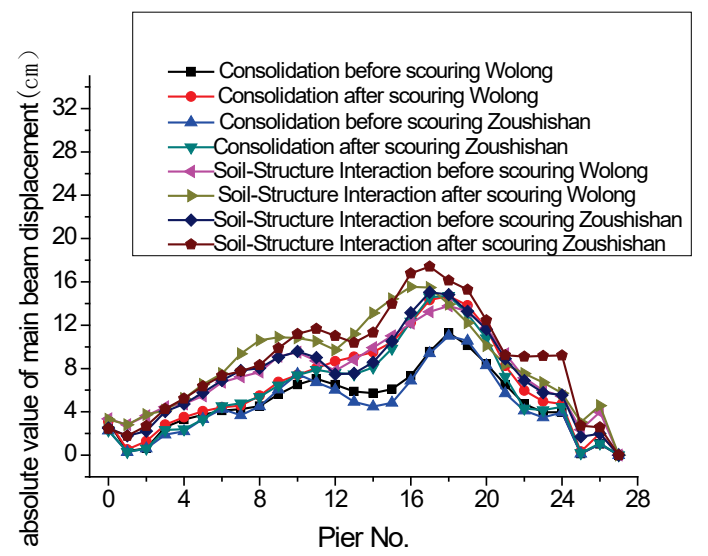

Figure 11 The maximum displacement of main girder along bridge in earthquake response

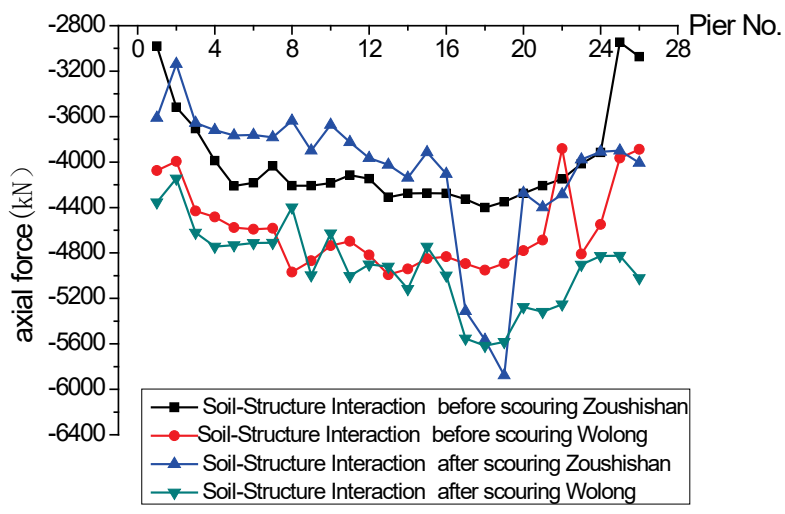

Figure 12 The maximum axial force of each pile

The calculation and analysis show that intense scour seriously influences force condition of bridge pile foundation. Under reoccurrence of strong earthquake, part of pile foundation will be subject to damage owing to excessive bending moment. And the intensified riverbed scouring will further weaken pile foundation stress. Therefore, bridge No. 3 requires consolidation and measures should be adopted to prevent riverbed scouring.

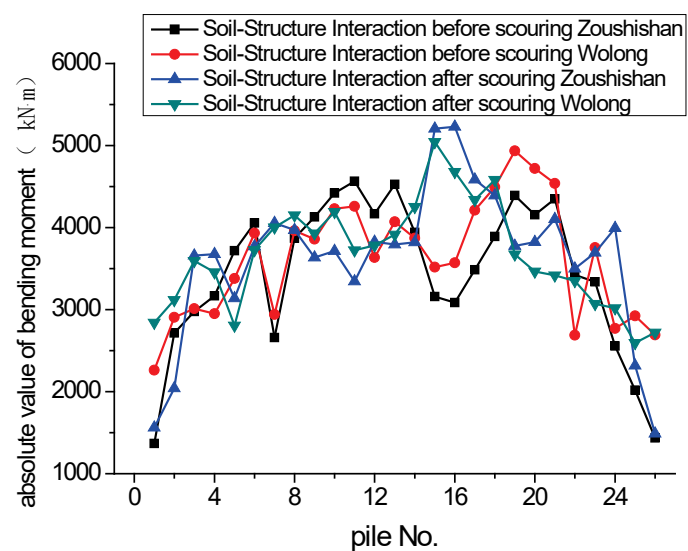

Figure 13 The maximum bending moment of each pile along the bridge

In addition, the prevention of illegal sand gravel collection to reduce exposure of pile foundation conflicts with project construction. This is management related issue for local government. Calculating based on runoff volume, which enjoys annual average of over ninety billion cubic meters. The exploitation of sand gravel should be on the environment protection basis and should promote "Calm Yangtze, Green Yangtze, Harmonious Yangtze, and Beautiful Yangtze". For serious-scour river, the lower reaches of reservoir dam break the balance of scour siltation, where there is only scour available without siltation. How to establish the balance between scour and siltation is a new major problem facing us.

\section{CONCLUSION}

Through combining real bridge test with theoretical analysis, and inputting the seismic wave of Wolong and Stone mountain, the analysis of the bearing capacity of bridge pile which considered the effect of erosion and once again strong earthquake could be got. Results are as follows:

(1) The bridge is originally designed stable under general operating condition, however affected by Wolong earthquake wave the No.9 pile foundation whose soil is soft will be subject to bending.

(2) Without considering strong earthquake, the vertical axial force of pier stud and bearing capacity for existing bridge satisfies requirement under scour, but flexural performance of pile foundation fails to meet requirement.

(3) Influenced by existing scour and strong earthquake, the bridge demonstrates instability. With pile foundation scoured and bridge undergoing strong earthquake, the axial force and bending moment of pier bottom are slightly less than before. In the main girder is observed increased displacement which causes an increase of maximum axial force and bending moment of pile foundation. The area where scour is serious will lead to great bending moment of pile foundation. And part of pile foundation will be damaged in the form of bending. 
(4) As the construction of Zipingpu reservoir breaks siltation balance, the flood is likely to intensively scour the lower reaches of bridge. This requires long-time hydrological and scour monitoring. And the effect exerted on pile foundation stability needs further researching.

Based on above-mentioned analysis, bridge No. 3 has been unstable and can no longer bear intensified scour and strong earthquake. The bridge requires consolidation. Still, measures should be considered to weaken scour or prevent further intensified scour.

\section{Acknowledgements}

This research was supported by National Natural Science Foundation of China (Grant No. 51508358, 4167020785, 41502242); Towns and villages Disaster Prevention and Mitigation Engineering Research Center of Sichuan Colleges and Universities funded projects (Grant No. CDPMV1403) and Research Innovation Teams funded projects of Sichuan Provincial Department of Educations (Grant No. 16TD0006).

\section{REFERENCES}

[1] Zhang, J., Jia, H. Y., Zheng, S. X. et al. (2016). Analysis of a high-pier railway bridge under spatial stochastic stationary and non-stationary earthquake excitations. Tehnicki VjesnikTechnical Gazette, 23(2), 465-475. https://doi.org/10.17559/TV-20151208071236

[2] Deng, J., Liu, T., Xie, W. et al. (2015). Study on Repaired Earthquake-Damaged Bridge Piers under Seismic Load. Advances in Materials Science \& Engineering, 2015(5), 110. https://doi.org/10.1155/2015/295392

[3] Chung, Y. S., Chang, K. P., \& Meyer, C. (2008). Residual Seismic Performance of Reinforced Concrete Bridge Piers After Moderate Earthquakes. Aci Structural Journal, 105(1), 87-95. https://doi.org/10.14359/19072

[4] Wu, Z. J., Che, A. L., \& Ghen, T. (2011). Warming effects on permafrost under earthquake motions and seismic stability of pile foundation of dry bridge. Materials Research Innovations, 15(sup1), s586-s589. https://doi.org/10.1179/143307511X12858957676957

[5] Hsu, H. L. \& Wang, C. L. (2000). Flexural-torsional Behaviour of Steel Reinforced Concrete Members Subjected to Rep-eated Loading. Earthquake Engineering \& Structural Dynamics, 29(5), 667-682. https://doi.org/10.1002/(SICI)1096-9845(200005)29:5<667::AIDEQE930>3.0.CO;2-Y

[6] Du, X. L., Chen, M. Q., \& Han, Q. (2011). Experimental evaluation of seismic performance of reinforced concrete hollow bridge columns. Journal of vibration and shock, 30 , 254-259. (in Chinese)

[7] Zhang, L., Goh, S. H., \& Liu, H. (2017). Seismic response of pile-raft-clay system subjected to along-duration earthquake: centrifuge test and finite element analysis. Soil Dynamics \& Earthquake Engineering, 92, 488-502. https://doi.org/10.1016/j.soildyn.2016.10.018

[8] Ma, K. \& Xu, Q. (2014). Seismic softening behavior of pileraft foundation constructed in clayey soil site subjected to far field earthquake. Journal of Vibroengineering, 16(2), 560574.

[9] Kumar, A., Choudhury, D., \& Katzenbach, R. (2016). Effect of Earthquake on Combined Pile-Raft Foundation. International Journal of Geomechanics, 16(5), 4016013 https://doi.org/10.1061/(ASCE)GM.1943-5622.0000637
[10] Luo, C., Yang, X., Zhan, C. et al. (2016). Nonlinear 3D finite element analysis of soil-pile-structure interaction system subjected to horizontal earthquake excitation. Soil Dynamics \& Earthquake Engineering, 84, 145-156. https://doi.org/10.1016/j.soildyn.2016.02.005

[11] Al-Defae, A. H. \& Knappett, J. A. (2015). Newmark sliding block model for pile-reinforced slopes under earthquake loading. Soil Dynamics \& Earthquake Engineering, 75, 265278. https://doi.org/10.1016/j.soildyn.2015.04.013

[12] Yuan, B.X., Sun, M., Wang Y.X. et al.(2019). Full 3D displacement measuring system for 3D displacement field of soil around a laterally loaded pile in transparent soil. $A S C E$ International Journal of Geomechanics, 19(5), 04019028. https://doi.org/10.1061/(ASCE)GM.1943-5622.0001409

[13] Wang, Y., Shan, S., \& Zhang, C. (2019). Seismic response of tunnel lining structure in a thick expansive soil stratum. Tunnelling and Underground Space Technology, 88, 250259. https://doi.org/10.1016/j.tust.2019.03.016

[14] GB 50011-2001. Code for seismic design of buildings. Beijing: China Architecture and Building Press, 2001. (in Chinese).

[15] GB 50011-2010. Code for seismic design of buildings. Beijing: China Architecture and Building Press, 2010. (in Chinese)

[16] Sichuan Jiaoda Civil Engineering Testing Consulting Co., Ltd. Test Report of Minjiang No. 3 Bridge, 2013, 2-18. (in Chinese)

[17] Ma, D. B., Li, Z. G., Duan, M. L, et al. (2012). Research on Foundation Soil Mass Property after Erosion and Bearing Capacity of Platform Pile Foundation. China Petroleum Machinery, 6, 54-58. (in Chinese)

[18] Huang, Y., Li, R., \& Zhu, W. J. (2014). Analysis of damage mechanism of small radius curve continuous beam bridges during the Wenchuan Earthquake. Earthquake Engineering and Engineering Dynamics, 34(Suppl), 383-388. (in Chinese)

[19] Wei, X., Fan, L. C., \& Wang, Q. J. (2002). Shake Table Test on Soil-Pile-Structure Interaction. China Civil Engineering Journal, 4, 91-97. (in Chinese)

[20] JTG/T B02-01-2008: Guidelines for Seismic Design of Highway Bridges. Beijing: China Communication press, 2008. (in Chinese)

[21] JTG/T B62-01-2008: Code for Design of Highway Reinforced Concrete and Prestressed Concrete Bridges and Culverts, Beijing: China Communication Press, 2012. (in Chinese)

[22] Chengdu Sichuan Jiaoda Civil Engineering Testing Consulting Co., Ltd. Construction design drawing of maintenance and consolidation for Minjiang No.3 Bridge, 2013, 2-18. (in Chinese)

[23] JTG D63-2007: Specifications for Design of Ground Base and Foundation of Highway Bridges and Culverts. Beijing: China Communication press, 2004. (in Chinese)

[24] JTG D60-2004: General Code for Design of Highway Bridge and Culverts. Beijing: China Communication press, 2004.

[25] Huang, Y. (2008). The performance of girder bridges in Wenchuan Earthquake and a new method for seismic protection. Earthquake Engineering and Engineering Dynamics, 28(5), 20-26. (in Chinese) 


\section{Contact information:}

Huang XIANBIN, Associate Professor

(Corresponding Author)

Civil Engineering, Sichuan Agricultural University,

Member of Sichuan Higher Education Engineering Research Center for Disaster

Prevention and Mitigation of Village Construction, Sichuan 611830, China

E-mail: hxianbin@sicau.edu.cn

\section{Liu CHENYANG, Master}

Civil Engineering, Sichuan Agricultural University,

Member of Sichuan Higher Education Engineering Research Center for Disaster

Prevention and Mitigation of Village Construction, Sichuan, 611830, China

E-mail: Cysc9495@163.com

Hou SONG, Master

State Grid Sichuan Electric Power Company Leshan Power Supply Company,

Sichuan, 614000, China

E-mail:18202816292@163.com

\section{Chen CHUNYANG,Master}

Civil Engineering, Sichuan Agricultural University,

Member of Sichuan Higher Education Engineering Research Center for Disaster

Prevention and Mitigation of Village Construction, Sichuan 611830, China

E-mail: 1428724458@163.com

\section{Mei YUJIAO, Master}

Civil Engineering, Sichuan Agricultural University,

Member of Sichuan Higher Education Engineering Research Center for Disaster

Prevention and Mitigation of Village Construction, Sichuan 611830, China

E-mail: $971868730 @ q q . c o m$

\section{Lei BO, Master}

Guang'an Vocational Technical College,

Guangan, Sichuan, 611830, China

E-mail: 350906886@qq.com

Huang YONG, Associate Professor Institute of Engineering Mechanics,

China Earthquake Administration,

Harbin, 150080, China

E-mail: 860429644@qq.com 